\title{
Evaluation of Reactivation of Inhibited Acetyl Cholinesterase Enzyme in Patients Intoxicated With Organophosphorus Insecticide
}

\author{
Alsayed Magdi Alsayed Farahat ${ }^{1}$, Magdy Abdel-Hai Ismael ${ }^{2}$, Sherif Fahmy Mahmoud ${ }^{2}$, \\ Abdel Aziz Abu El- Fotouh Ghanem ${ }^{3}$
}

\begin{tabular}{|c|c|}
\hline & ABSTRACT \\
\hline $\begin{array}{l}\text { KEYWORDS } \\
\text { Organophosphorus, } \\
\text { Oxime, } \\
\text { Mansoura, } \\
\text { Damietta. }\end{array}$ & $\begin{array}{l}\text { Pesticides are a large and heterogeneous group of chemicals which have long been } \\
\text { used to control and repel pests in different fields. The organophosphates are the most } \\
\text { widely used pesticides in industry, agriculture and houses. This study intends to } \\
\text { evaluate the effectiveness of obidoxime therapy for reactivation of cholinesterase } \\
\text { enzyme and its correlation with severity of poisoning among organophosphorus } \\
\text { poisoning cases presented to Mansoura poisoning control unit (received oxime as aline } \\
\text { of therapy) and Damietta general hospital, (did not received oxime as aline of therapy) } \\
\text { during the period from } 1^{\text {st }} \text { March } 2015 \text { to the end of February } 2017 \text {. A total number of } \\
303 \text { patients presented with acute anticholiesterase poisoning (150 in Damietta and } 153 \\
\text { in Mansoura Emergency Hospital). A total of } 250 \text { cases were diagnosed to be } \\
\text { organophosphorus by TLC }\{112 \text { in Damietta and } 138 \text { in Mansoura emergency hospital\} } \\
\text { and only } 200 \text { of them were included in this study according to exclusion criteria. Data } \\
\text { on evaluation of obidoximes in treatment of organophosphorus (OP) poisoning } \\
\text { incorporating the maximal clinical parameters and comparing the two groups in an } \\
\text { unbiased manner, revealed that the use of obidoximes decreased the required dose of } \\
\text { atropine and duration of hospital stay when compared with atropine alone. It is clear } \\
\text { that there may be potential benefit from oximes as acetyl cholinesterase (AChE) } \\
\text { activity is clearly increased by treatment. }\end{array}$ \\
\hline
\end{tabular}

\section{Introduction}

Pesticides are a large and heterogeneous group of chemicals which have long been used to control and repel pests (Mostafalou and Abdollahi, 2016). These compounds can affect mammalian systems by inhibiting acetylcholinesterase at the synapses and muscular junctions, which may result in

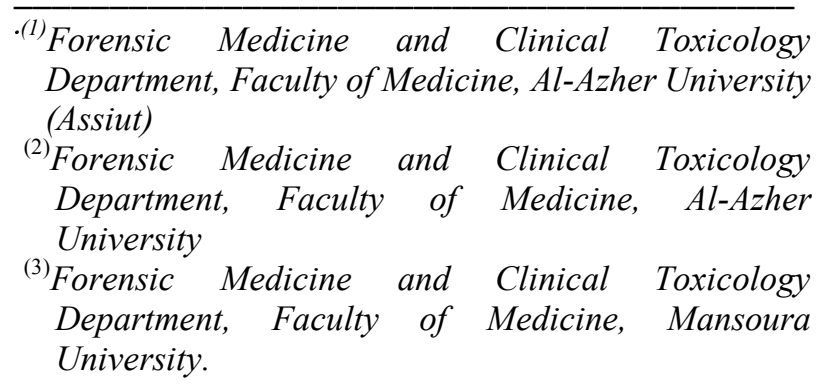

hypercholinergic preponderance. Apparently, the mechanisms causing brain, muscle or other organ damage by organophosphorus (OP) are mostly related to a change in oxidantantioxidant balance, which in turn results in free radical-mediated injury, as supported by many studies (Abdollahi et al., 2004; Rahimi et al., 2006; Jamshidi et al., 2009; Mohammadi et al., 2011; Saadi and Abdollahi, 2012).

A WHO task group has lately estimated that the incidence of pesticide poisoning may rise to three million cases and result in more than 250,000 deaths (World Health Organization, 2015). Most of these deaths follow a deliberate self ingesion particularly in young productive age group (World Health Organization, 2004). 
Medication for OP poisoning consists of high-dose intravenously administered atropine to temporarily block these cholinergic effects plus an oxime to restore the activity of the acetylcholinesterase enzyme. There is no clear evidence of benefit from oxime therapy in OP poisoning (Buckley et al., 2011). Atropine therapy is known to improve outcome (Eddleston et al., 2008; Blain, 2011). The reviewers found that there is no enough research to see whether oximes are actually effective or to define the doses that are more likely to be helpful. More research is needed before any firm conclusions can be drawn. Notably, research studies addressing the effectiveness and safety of the administration of oximes in acute organophosphorus pesticide-poisoned patients are still lacking. That is why the current study was conducted.

The present work was conducted to evaluate the effectiveness of obidoxime therapy for reactivation of cholinesterase enzyme and its correlation with severity of poisoning.

\section{Subjects and Methods}

The present study is a case control study carried on 3 groups during the period from 1st March 2015, to the end of February 2017:

Group I: included one hundred patients admitted to Damietta General Hospital, Damietta, Egypt and presented with acute organophosphorus poisoning and did not received oxime as a line of therapy.

Group II: included one hundred patients admitted to Mansoura Poisoning Control Unit, Mansoura University, Egypt, presented with acute organophosphorus poisoning who received oxime as a line of therapy.

Group III: included one hundred healthy volunteer with no previous history of organophosphorus poisoning (relatives of the subjects).

Inclusion criteria were age: 5-60 years and patient intoxicated with organophosphorus compound (confirmed by TLC). Exclusion criteria were; anaemia, neurological diseases, patients with the history of consumption of any compound other than OPCs and refered cases previously treated in another hospital .

Their personal and medical data was recorded in a special observation sheet. Clinical outcome, pseudocholinesterase level, and true cholinesterase level were assessed on adimission for both group I and group II together with assessment of both pseudocholinesterase and true cholinesterase levels for the control group. Stomach contents were collected from patients of test groups.

Clinical severity was categorized according to Peradeniya organophosphorus poisoning (POP) scale. Accordingly patients were grouped into mild (POP score 0-3), moderate (POP score 4-7) and severe poisoning (POP score 8-11) (Senanayake et al., 1993).

\section{Methods:}

1-Thin-Layer Chromatography (TLC) according to Jaiswal et al. (2008) for diagnosis of organophosphorus intoxication and exclusion of other pesticide.

(A) Chemicals' preparation

i. Standard solution: $1000 \mu \mathrm{g}$ solution of malathion in acetone was prepared by dissolving $0.1 \mathrm{gm}$ of known malathion standard in $100 \mathrm{ml}$ acetone.

ii. Visualising reagent: 0.5 gm of palladium chloride was dissolved it in $100 \mathrm{ml}$ of water \& then acidified upto $\mathrm{pH} 3$, by using drops of concentrated hydrochloric acid.

iii. Preparation of TLC tank: A rectangular glass chamber $(29 \times 9.5 \times 27 \mathrm{~cm})$ with an airtight lid was perfectly saturated with vapours of solvent system for 20-30 min by putting a filter paper in three walls of TLC chamber. The spotted plate was inserted and sealed to maintain airtight environment.

(B) Extraction from stomach contents:

Twenty milliliter of stomach contents from a volunter were spiked with $6 \mathrm{ml}$ of 
malathion and kept in incubator overnight. It was mixed with $20 \mathrm{ml}$ of $10 \%$ sodium tungstate solution and $30 \mathrm{ml}$ of $1 \mathrm{~N}$. Sulphuric acid (6.9 concentrated sulphoric acid and dilute it to 250 ml water), shaken for two minutes and then filtered. The residue was washed twice by 30 $\mathrm{ml}$ of $0.1 \mathrm{~N}$ sulphuric acid. The washings were collected and mixed with the filtrate, transferred into a separating funnel and extracted thrice with $40 \mathrm{ml}$ portions of $\mathrm{n}$ hexane. The hexane layers were combined, passed through anhydrous sodium sulphate and the solvent was removed by evaporation.

C) Procedure

The extracted sample along with the standard sample was spotted on the TLC plate $(20 \mu \mathrm{l})$. The spots were allowed to dry and spotted plate was developed with solvent system acetone : benzene (70:30).

The plate was allowed to dry and then spots were viewed using the palladium chloride, visualising reagent.

There were different spots from different pesticide visualised in some samples.

2-Pseudocholinesterase estimation according Waber (1966).

3-True cholinesterase level according to Ellman et al. (1961).

\section{Statistical Analysis:}

Data entry and analysis was performed using SPSS statistical package version 20 (SPSS, Inc., Chicago, IL, USA). The quantitative data was presented as mean \pm standard deviation if equally distributed and presented as median if unequally distributed. The samples were analyzed for normality of distribution by Kolmogorov-Smirnov test. The qualitative data was presented as number and percentage.

Chi-square test was used to compare the difference in nominal and ordinal data between the three studied group. Mann-Whitney test was used to compare median values of the three studied groups, student t- test was used to compare mean values between group I and II patients. Wilcoxon Signed Ranks Test was used to compare the change of true cholinesterase and pseudo-cholinesterase levels over time in group I and II patients. The accepted level of significance in this work was stated at $0.05, \quad(\mathrm{p}<0.05$ was considered significant).

\section{Results}

A total of 303 patients presented with acute anticholiesterase poisoning (150 from Damietta and 153 from Mansoura Emergency Hospital). A total of 250 cases were diagnosed to be organophosphorus by TLC $\{112$ from Damietta and 138 from Mansoura Emergency Hospital $\}$ and only 200 of them were included in this study according to exclusion criteria

Clinical evaluation of patients in the two treatment groups according to Peradeniya Organophosphorus Poisoning (POP) Scale are summarised in table (1). 
Table (1): Severity of organophosphorus poisoning among the two tested groups according to Peradeniya Organophosphorus Poisoning (POP) Scale (n: 200).

\begin{tabular}{|c|c|c|c|c|}
\hline Parameters & Scale & $\begin{array}{l}\text { Group I } \\
(n=100)\end{array}$ & $\begin{array}{l}\text { Group II } \\
(n=100)\end{array}$ & $\begin{array}{c}\text { p value (Chi-Square } \\
\text { Test) }\end{array}$ \\
\hline \multirow{3}{*}{ Pupil size } & $\mathbf{0}$ & 34 & 25 & \multirow{3}{*}{.226} \\
\hline & 1 & 52 & 64 & \\
\hline & 2 & 14 & 11 & \\
\hline \multirow{3}{*}{ Respiratory rate } & $\mathbf{0}$ & 38 & 34 & \multirow{3}{*}{.840} \\
\hline & 1 & 49 & 52 & \\
\hline & 2 & 13 & 14 & \\
\hline \multirow{3}{*}{ Heart rate } & $\mathbf{0}$ & 91 & 95 & \multirow{3}{*}{.430} \\
\hline & 1 & 7 & 3 & \\
\hline & 2 & 2 & 2 & \\
\hline \multirow{3}{*}{ Fasciculation } & $\mathbf{0}$ & 52 & 59 & \multirow{3}{*}{.140} \\
\hline & 1 & 46 & 35 & \\
\hline & 2 & 2 & 6 & \\
\hline \multirow{3}{*}{$\begin{array}{c}\text { Consciousness } \\
\text { level }\end{array}$} & $\mathbf{0}$ & 77 & 71 & \multirow{3}{*}{.134} \\
\hline & 1 & 14 & 24 & \\
\hline & 2 & 9 & 5 & \\
\hline \multirow{2}{*}{ Seizures } & $\mathbf{0}$ & 94 & 92 & \multirow{2}{*}{.391} \\
\hline & 1 & 6 & 8 & \\
\hline \multirow{3}{*}{ Total score } & Mild (0-3) & 77 & 75 & \multirow{3}{*}{.945} \\
\hline & $\begin{array}{l}\text { Moderate } \\
(4-7)\end{array}$ & 22 & 24 & \\
\hline & Severe (8-11) & 1 & 1 & \\
\hline
\end{tabular}

n: number, Group I: Damietta, Group II: Mansoura.

Statistical analysis for the difference between the pseudo-cholinesterase levels at the time of presentation of the two studied groups I \& II showed no significant difference ( $\mathrm{p}$ value
$=0.146$ ), groups I \& III and groups II \& III showed significant difference with $\mathrm{p}$ value $=$ 0.001 as demonstrated in table (2). 
Table: (2): Pseudo-cholinesterase level in the studied groups $(n=300)$.

\begin{tabular}{|l|l|c|c|c|}
\hline \multicolumn{2}{|c|}{} & $\begin{array}{c}\text { Group I } \\
(\mathbf{n = 1 0 0})\end{array}$ & $\begin{array}{c}\text { Group II } \\
(\mathbf{n = 1 0 0})\end{array}$ & $\begin{array}{c}\text { Group III } \\
(\mathbf{n = 1 0 0})\end{array}$ \\
\hline $\begin{array}{l}\text { Pseudo-cholinesterase at the time of } \\
\text { presentation }\end{array}$ & Median & 1315.00 & 1515.00 & 6451.00 \\
\cline { 2 - 5 } & Range & $124.00-2720.00$ & $300.00-2843.00$ & $3086.00-7973.00$ \\
\hline Mann Whitney test (groups I \& II) & \multicolumn{3}{|l}{0.146} \\
\hline Mann Whitney test (groups I \& III) & \multicolumn{3}{|l|}{0.001} \\
\hline Mann Whitney test (groups II\& III) & \multicolumn{3}{|l}{0.001} \\
\hline
\end{tabular}

Statistical analysis for the difference between the true-cholinesterase levels at the time of presentation of the two studied groups I \& II; groups I \& III and groups II \& III showed significant difference with $\mathrm{p}$ value $=$ $0.002 ; \quad 0.001$ and $\quad 0.001$ respectively as demonstrated in table (3).

Table (3): True-cholinesterase level in the studied groups $(n=300)$.

\begin{tabular}{|l|l|c|c|c|}
\hline \multicolumn{2}{|c|}{} & $\begin{array}{c}\text { Group I } \\
(\mathbf{n = 1 0 0 )}\end{array}$ & $\begin{array}{c}\text { Group II } \\
(\mathbf{n = 1 0 0})\end{array}$ & $\begin{array}{c}\text { Group III } \\
(\mathbf{n = 1 0 0})\end{array}$ \\
\hline $\begin{array}{l}\text { True-cholinesterase level } \\
\text { (IU/L) }\end{array}$ & Median & 4.30 & 5.30 & 8.84 \\
\cline { 2 - 5 } & Range & $1.30-7.90$ & $1.20-8.20$ & $7.14-10.1$ \\
\hline P value (Mann-Whitney test) (groups I \& II) & & 0.002 & \\
\hline P value (Mann-Whitney test) (groups I \& III) & \multicolumn{3}{|l}{0.001} \\
\hline P value (Mann-Whitney test) (groups II \& III) & \multicolumn{3}{|l}{0.001} \\
\hline
\end{tabular}

Group I: Damietta, Group II: Mansoura, Group III: normal population.

Statistical analysis for the difference between Endotracheal intubation and mechanical ventilation for the two test groups showed no significant difference $(\mathrm{p}$ value $=$ 0.519). As regard atropine dose, statistical analysis for the difference between the two test groups showed significant difference ( $p$ value
$=0.001)$. As regard hospital stay, significant difference was detected between the two test groups $(\mathrm{p}$ value $=0.001)$. Meanwhile, outcome of treatment showed no significant difference ( $p$ value $=0.329$ ) between the two test groups (Table 4). 
Table (4): Statistical analysis of the difference in the hospital management $(n=200)$.

\begin{tabular}{|c|c|c|c|c|}
\hline & & $\begin{array}{l}\text { Group I } \\
(n=100)\end{array}$ & $\begin{array}{c}\text { Group II } \\
(\mathrm{n}=100)\end{array}$ & P value \\
\hline \multirow{2}{*}{$\begin{array}{l}\text { Endotracheal } \\
\text { intubation and } \\
\text { mechanical ventilation }\end{array}$} & Present & 28 & 24 & \multirow{2}{*}{0.519} \\
\hline & Absent & 72 & 76 & \\
\hline \multirow[b]{2}{*}{ Atropine dose in mg. } & Median & 150.00 & 73.50 & \multirow[b]{2}{*}{$0.001 *$} \\
\hline & Range & $\begin{array}{c}40.00 \\
399.00\end{array}$ & $\begin{array}{c}15.00 \\
396.00\end{array}$ & \\
\hline \multirow[b]{2}{*}{ Hospital stay(days) } & Median & 9.0000 & 5.00 & \multirow[b]{2}{*}{$0.001 *$} \\
\hline & Range & $\begin{array}{c}2.00 \\
45.00\end{array}$ & $\begin{array}{c}2.00 \\
45.00\end{array}$ & \\
\hline \multirow{3}{*}{$\begin{array}{l}\text { Outcome (number of } \\
\text { patients) }\end{array}$} & $\begin{array}{l}\text { Survival without } \\
\text { endotracheal intubation }\end{array}$ & 72 & 76 & \multirow{3}{*}{0.329} \\
\hline & $\begin{array}{l}\text { Survival with endotracheal } \\
\text { intubation }\end{array}$ & 16 & 18 & \\
\hline & Death & 12 & 6 & \\
\hline
\end{tabular}

n: number, Group I: Damietta, Group II: Mansoura.

\section{Discussion}

Current therapy for OP poisoning requires resuscitation with the use of oxygen and atropine, followed by administration of an oxime (such as obidoxime) to reactivate AChE, plus benzodiazepines to mitigate neurological impairment (Ballantyne and Marrs, 1992 ; Bird, et al., 2003; Eddleston et al., 2004; Eddleston et al., 2005; Sivilotti et al., 2006).

The present study revealed marked reduction of serum pseudocholinesterase on admission in each of the tested groups, with no significant difference between both groups. There was decrease in serum pseudocholinesterase activity in OP poisoning cases when compared to controls as previosly reported by Sozmen et al. (2007) and Gazzi et al. (2014).
Also, the study revealed marked reduction of true-cholinesterase levels on admission in each of the test groups, with significant difference between both groups and there was fall in true-cholinesterase activity in $\mathrm{OP}$ poisoning cases when compared to controls a logical finding that was reported also by BalaliMood and Shariat (1998).

The study revealed no significant difference between the two studied groups regarding peradeniya OP poisoning (POP) scale.

Peradeniya Organophosphorus Poisoning (POP) scale was calculated for all patients on admission. Both groups included nearly equal number of mild cases $(77 \%)$ of group I and (75\%) of group II and moderate cases $(22 \%)$ of group I and (24\%) of group II, and sever cases only $(1 \%)$ of both groups with no significant statistical difference between the two groups. This is in accordance with Banerjee et al. (2014). 
Regarding to the pupil size, respiratory rate, heart rate, conscious level changes, fasciculations and seizures, there was no significant statistical difference between two groups. Similar findings were observed by Shah Harsh et al. (2012) and Banerjee et al. (2014).

Efficacy outcome in either group was analyzed through mortality, requirement for ventilator support, atropine dose and the duration of stay in hospital (in days). In relation to hospital management, the study revealed significant difference between the two studied groups regarding patient's atropine dose and hospital stay.

As regard atropine dose, patients on obidoximes therapy (group II), required less atropine doses. This findings is in agreement with Pawar et al. (2006), who showed that a high-dose regimen of pralidoxime reduces the total dose of atropine needed, but disagrees with Balali-Mood and Shariat (1998) who found that patients on obidoximes, pralidoxime therapy required more atropine doses.

Chugh et al. (2005) found that there was no statistical difference between the two groups "Atropine Alone" and "Atropine with Pralidoxime (PAM)" regarding atropine requirements, total amount of atropine used and its duration. This may be due to difference in cholinesterase reactivator used in both studies.

In addition, atropine requirement of our patients was low in obidoximes therapy (group II) due to reactivation of inhibited acetyl cholinesterase enzyme. This findings is in accordance with Thiermann et al. (2009) who found that atropine requirement $(<0.01$ $\mathrm{mg} / \mathrm{kg} / \mathrm{h}$ ) when true choline esterase was $>10 \%$ growed rapidly at true choline esterase $<10 \%$.

Atropine dosage regimen for acute OP poisoning in adults has never been studied in a randomized, controlled trial, and there is considerable variation in textbook recommendations. The most important end-point for adequate atropine therapy is clear lung secretions and reversal of the muscarinic toxic syndrome (Howland, 2011). Reducing the dose of atropine is an important clinical issue as its administration in high doses is frequently associated with dangerous adverse health effects.

The current study revealed significant difference between the two studied groups regarding the duration of hospital stay. Length of hospital stay decrease in the group II when compared to group I. The mean stay in hospital recorded in the report of the Emerson et al. (1999) study of 69 patients between 1987 and 1996 in Western Australia was 7 days (1-25 days).

The current study disagrees with Duval et al. (1991); Chugh et al. (2005); Eddleston et al. (2009) and Banerjee et al. (2014) who found that there was no statistical difference between the two studied groups "Atropine Alone" and "Atropine with Pralidoxime (PAM)" regarding length of hospital stay. This is probably due to the difference in the type of cholinesterase reactivator.

In relation to outcome, the number of survived patients who needed endotracheal intubation and mechanical ventilation were nearly equal in both groups with no significant statistical difference between two groups. This is in comparison with Tilottama et al. (2016). The survival rate in OPC poisoning requiring mechanical ventilation varied between $13 \%$ and $50 \%$ in a variety of settings (Bardin et al., 1987; Rajapakse and Wijesekera, 1989; Yen et al., 2000; Abedin et al., 2012).

Regarding patients needed ventilation were nearly equal number with no significant statistical difference between two tested group. This is in accordance with Banerjee et al. (2014). However, Peter et al. (2006) and Rahimi et al. ( 2006) observed that there was no beneficial effect of oximes in reducing ventilator requirements. Moreover, they reported that there 
was an increased need for intensive care therapy when oximes were used.

Alternatively, another study found that pralidoxime reduces significantly the need for intubation and the duration of mechanical ventilation (Pawar et al., 2006).

The current study had a mortality rate of $6 \%$ of patients in group II which was less than group I $(12 \%)$ with insignificant difference between both group. The same results was observed by Balali-Mood and Shariat (1998) who reported that the reactivation of $\mathrm{AChE}$ is an important factor for the patient's recovery as judged by the $100 \%$ recovery in the pralidoxime group. This difference may be also due to presence of specialized poisoning control centre in Mansoura Emergency Hospital.

Our result disagrees with Chugh et al. (2005) who found that mortality occurred in "atropine with pralidoxime (PAM)" group $(6.66 \%)$ while no mortality (100\% recovery) in "atropine alone" group was noticed. Also, Peter et al. (2006) observed that there was no beneficial effect of oximes on mortality rate. Moreover, they reported that there was an increased need for intensive care therapy when oximes were used.

Banerjee et al. (2014) found that case fatality was higher $(18.33 \%)$ in group 2 patients "Atropine with Pralidoxime (PAM)" as compared to those in group $1(13.33 \%)$, that is, those receiving "Atropine Alone".

In the present study, mortality occurred in both groups. The mortality in the current study may be related to differences in pattern and severity of poisoning depending on various factors such as the type of $\mathrm{OP}$ compound consumed, its amount, the time interval before hospitalization, the availability of effective treatment "Atropine with obidoxime" or "Atropine Alone" and the general health of the patient (Eddleston, 2000; El-Ebiary et al., 2016).

\section{Conclusion}

The present data on evaluation of obidoximes in treatment of OP poisoning incorporating the maximal clinical parameters and comparing the two groups in an unbiased manner, revealed that the use of obidoximes decreased the required dose of atropine and duration of hospital stay when compared with atropine alone. It is clear that there may be potential benefit from oximes as AChE activity is clearly increased by treatment.

This study has taken care of all variables; hence, it is a comprehensive, useful, prospective trial from this country which delivers the clear message that obidoximes showed clinical benefits in the management of OP poisoning.

\section{References}

Abdollahi, M.; Ranjbar, A.; Shadnia, S.; et al. (2004): "Pesticides and oxidative stress: a review". Med. Sci. Monit.; 10(6): 141-147.

Abedin, M.J.; Abu Sayeed, A.; Basher, A.; et al. (2012): "Open-label randomized clinical trial of atropine bolus injection versus incremental boluses plus infusion for organophosphate poisoning in Bangladesh". J. Med.Toxicol.; 8:108117.

Balali-Mood, M. and Shariat, M. (1998): "Treatment of organophosphate poisoning. Experience of nerve agents and acute pesticide poisoning on the effects of oximes". J. Physiol. Paris, 92(5-6):375-378.

Ballantyne, B. and Marrs, T.C. (1992): Overview of the biological and clinical aspects of organophosphates and carbamates. In: Clinical and Experimental Toxicology of Organo- 
phosphate and Carbamates. Butterworth Heinemann, Oxford, P.P. 3-14.

Banerjee, I.; Tripathi, S.K. and Sinha, R.A. (2014): "Efficacy of pralidoxime in organophosphorus poisoning:

Revisiting the controversy in Indian setting". J. Postgrad. Med., 60:27-30.

Bardin, P.G.; Van Eeden, S.F. and Joubert, J.R. (1987): "Intensive care management of acute organophosphate poisoning: a 7-year experience in the Western Cape". S. Afr. Med. J., 72:593-597.

Bird, S.; Gaspari, R.J. and Dickson, E.W. (2003):"Early death due to severe organophosphate poisoning is a centrally mediated process". Acad. Emerg. Med., 10:295-298.

Blain, P.G. (2011): "Organophosphorus poisoning (acute) ". Clin. Evid. (Online), 2011: 2102.

Buckley, N.A.; Eddleston, M.; Li, Y.; et al. (2011): "Oximes for acute organophosphate pesticide poisoning". Cochrane Database Syst Rev; CD005085. A systemic review on effectiveness and safety of oximes in human organophosphate poisoning.

Chugh, S.N.; Navneet, Aggarwal.; Surekha, Dabla.; et al. (2005): "Comparative evaluation of "Atropine Alone" and "Atropine with Pralidoxime (PAM)" in the management of organophosphorus poisoning". Indian Academy of Clinical Medicine (JIACM), 6(1): 3337.

Duval, G.; Rakouer, JM.; Tillant, D.; et al. (1991): "Acute poisoning by insecticides with anticholinesterase activity. Evaluation of the efficacy of a cholinesterase reactivator, pralid oxime". J. Toxicol. Clin. Exp., 11:51-58.

Eddleston, M. (2000): "Patterns and problems of deliberate self-poisoning in the developing world". Q. J. Med., 93:715731.

Eddleston, M.; Dawson, A.; Karalliedde, L.; et al. (2004): "Early management after self-poisoning with an organophosphorus or carbamate pesticide - a treatment protocol for junior doctors". Crit. Care. Dec., 8(6):R 391-397.

Eddleston, M.; Eyer, P.; Worek, F.; et al. (2005): "Differences between organophosphorus insecticides in human selfpoisoning: a prospective cohort study". Lancet, 366:1452-1459.

Eddleston, M.; Mohammed, F.; Davies, J.O.; et al. (2008): "Medical management of acute organophosphorus poisoning". Lancet, 371(9612): 597-607.

Eddleston, M.; Eyer, P.; Worek, F.; et al. (2009): "Pralidoxime in acute organophosphorus insecticide poisoning - a randomised controlled trial". PLoS medicine 6:e1000104.

El-Ebiary, A.A.; Elsharkawy, R.E.; Soliman, N.A.; et al. (2016): "N-acetylcysteine in acute organophosphorus pesticide poisoning: A randomized clinical trial". Basic \& Clinical Pharmacology \& Toxicology, Doi: 10.1111/ bcpt.12554.

Ellman, G.L.; Courtney, K.D.; Andres, V.; et al. (1961): "A new and rapid colorimetric determination of acetylcholinesterase activity". Biochemical Pharmacology, 7:88-95.

Emerson, G.M.; Gray, N.M.; Jelinek, G.A.; et al. (1999): "Organophosphate poisoning in Perth, Western Australia, 1987- 1996". J. Emerg. Med., 17:273-277. 
Gazzi E.N.; Sorodoc V.; Petris O.; et al. (2014): "Butyryl - cholinesterase activity- biomarker for predicting the outcome in acute cholinesterase inhibitor poisoning - a 30-year retrospective analysis". Rev. Med. Chir. Soc. Med. Nat. Iasi., 118:971978.

Howland, M.A. (2011): Antidotes in depth: atropine. In: Flomenbaum NE, Goldfrank LR, Hoffman RS et al. (eds). Goldfrank's Toxicologic Emergencies. McGraw - Hill Professional, New York, P.P. 500507.

Jaiswal, A.K.; Kaur, A.; Millo, T.; Kumar, A. and Gupta, M. (2008): "Determination of malathion in blood and urine using thin-layer chromatography". Journal of Indian Academy of Forensic Medicine, 30(1): 15-21.

Jamshidi, H.R.; Ghahremani, M.R.; Ostad, S.N.; et al. (2009): "Effects of diazinon on the activity and gene expression of mitochondrial glutamate dehydrogenase from rat pancreatic Langerhans islets". Pestic. Biochem. Physiol., 93(1): 23-27.

Mohammadi, H.; Karimi, G.; Shafiee, H.; et al. (2011): "Benefit of nanocarrier of magnetic magnesium in rat malathion-induced toxicityand cardiac failure using non-invasive monitoring of electrocardiogram and blood pressure". Toxicol. Ind. Health; 27(5), 417-429.

Mostafalou S. and Abdollahi, M. (2016): "Pesticides: an update of human exposure and toxicity". Archives of Toxicology, 2(91):549-599.
Parate, T.; Parate, S.; Bhalerao, N. and Agrawal, N. (2016): "Clinical profile of patients with organophosphorus poisoning in an intensive care unit in a tertiary care hospital" Global J. Research and Analysis, 5(4):438-440.

Pawar, K.S.; Bhoite, R.R.; Pillay, C.P.; et al. (2006): "Contiuous pralidoxime infusion versus repeated bolus injection to treat organophosphorus pesticide poisoning: A randomized controlled trial". Lancet, 368(9553): 2136-2141.

Peter, J.V.; Moran, J.L. and Graham, P. (2006): "Oxime therapy and outcomes in human organophosphate poisoning: An evaluation using meta-analytic techniques". Crit. Care Med., 34:502-510.

Rahimi, R.; Nikfar, S. and Abdollahi, M. (2006): "Increased morbidity and mortality in acute human organophosphate-poisoned patients treated by oximes: a meta-analysis of clinical trials". Hum. Exp. Toxicol., 25(3):157162.

Rajapakse, V.P. and Wijesekera, S. (1989): "Outcome of mechanical ventilation in Sri Lanka". Ann. R. Coll. Surg. Engl., 71:344-346.

Saadi, H.S. and Abdollahi, M. (2012): "The importance of pesticides effects on human reproduction in farmers". Int. J. Pharmacol., 8(46):7-9.

Sozmen, B.; Peker, S.; Kaya, U.; Erkan, M. and Sozmen, EY. (2007): "Markers of long-term exposure to organophosphorous pesticides in farmers who work in viniculture and tobacco production in Turkey". Toxicol. Mech. Methods, 17:379-384.

Senanayake, N.; de Silva, H.J. and Karalliedde, L.A. (1993): "Scale to assess severity in organophosphorus 
intoxication: POP scale". Hum. Exp. Toxicol., 12:29-39.

Shah, H.D.; Prakash, M.V. and Ram, O.V. (2012): "Acute organophosphorus poisoning and clinical admission score association among patients admitted in emergency ward of a tertiary teaching hospital of medical college". Journal of Pharmaceutical and Biomedical Sciences, 17(17):1-5.

Sivilotti, M.L.A.; Bird, SB.; Lo, J.C.Y.; et al. (2006): "Multiple centrally acting antidotes protect against severe organophosphate toxicity". Acad. Emerg. Med.; 13:359-364.

Thiermann, H.; Worek, F.; Eyer, P. et al. (2009): "Obidoxime in acute organophosphate poisoning: 2: PK/PD relationships". Clin. Toxicol.; 47: 807-813.

Waber, H. (1966): "Kinetic colorimetric method for detection of cholin- esterase". Dtsch. Med. Wschr., 91:1927.

World health organization (WHO) (2004): "The impact of pesticides on health. Preventing intenational and unintentional deaths from pesticide poisoning Geneva".

World Health Organization (WHO) (2015): "Preventing intentional and unintentional deaths from pesticide poisoning, the impact of pesticides on health". Available at : http://www.who.int/ mental_health/prevention/suicide/en/Pest icidesHealth2.pdf ].

Yen, D.H.; Yien, H.W.; Wang, L.M.; et al. (2000): "Spectral analysis of systemic arterial pressure and heart rate signals of patients with acute respiratory failure induced by severe organ phosphorus in applicators of agricultural pesticides in Majes-Arequipa" (Peru). J. Occup. Med. Toxicol., 1:27. 


\section{تقييم تنشيط الكوليز إستريز فى مرضى التسمم بالمييدات الحشرية الفوسفورية}

\section{السيد مجدي السيد فرحات}

قسم الطب الثرعي والسموم الإكلينيكية، كلية الطب، جامعة الأزهر بأسيوط

مجلى عبد الحى إسماعيل ، شريف فهمى محمود

قسم الطب الثرعي والسموم الإكلينيكية، كلية الطب، جامعة الأزهر

\section{عبد المزيز أبو الفتوح غانم}

قسم الطب الثرعي والسموم الإكلينيكية، كلية الطب، جامعة المنصورة

المبيدات هي مجموعة كبيرة وغير متجانسة من المو اد الكيميائية التي تستخدم ومنذ فترة طويلـة للسيطرة

على الآفات وصدها في مختلف المجالات. المبيدات الفوسفورية العضوية من أكثر المبيدات الثائعة الاستخدام فى الصناعة و الزر اعة و المنازل وتهدف هذه الدر اسة إلى تقييم فاعلية العلاج بالأوبيدوكسيم لإعادة تنشيط انزيم الكولين استر از وارتباطه مع شدة التسمم بين حالات التسمم كان عدد المرضى المصابون بالتسمم الحساد بمبيدات

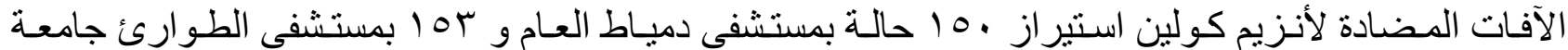

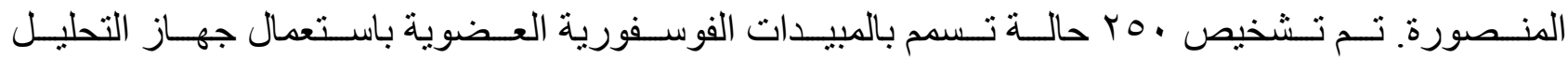

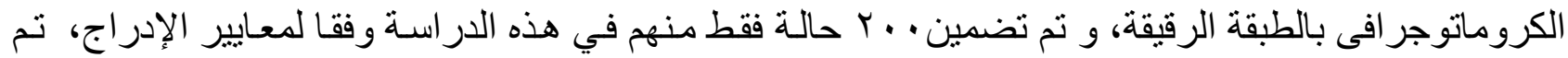
عمل الفحوصـات المعمليه الأتيها بعد دخول المرضـى مباشـرة وقبل تلقى العلاج، نشـاط انزيم الكولين استيراز

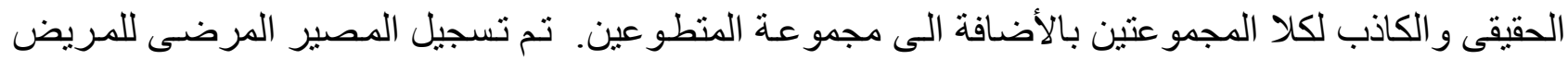
عند الخروج من الوحدة ومدة البقاء فى المستشفى والزمن الذى يسبق الاخول للوحدة بعد التعرض للتسمم وقد تم

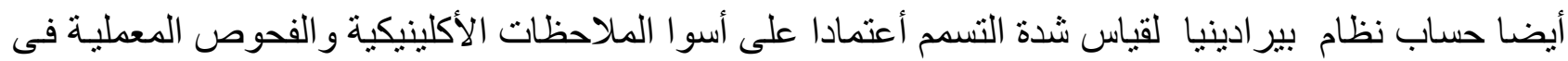
أول § Y سـاعة بعد الدخول. كشفت بياناتنا عن تقييم الأوبيدوكسيم في علاج التسمم بمبيدات الآفات المضادة

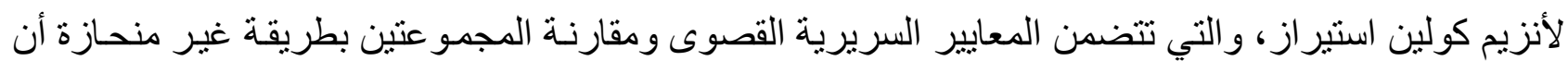

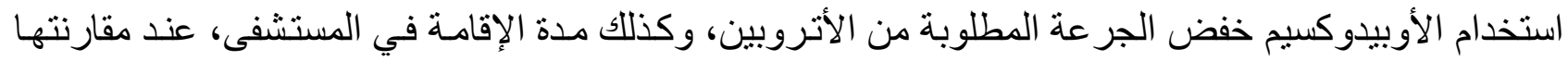

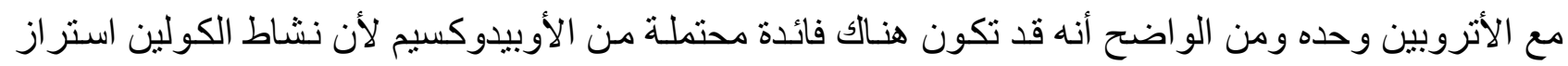
يزداد بشكل و اضح من خلال العلاج. 